\title{
COMPARATIVE STUDY ON DIFFERENT METHODS OF EXPERIMENTAL ARTHRITIS INDUCTION IN EQUINE
}

Ahmed MA. Elmesiry BVSc, MVSc; Ali A. Mansour, BVSc, MVSc, PhD; Magdi A. Seleim BVSc, MVSc, PhD

\begin{abstract}
Animal models for osteoarthritis (OA) are essential for studying the disease process and evaluating different therapeutic protocols. To date, no ideal OA animal model has been described. This study is a trial to find an equine osteoarthritic model that mimics the naturally occurring one in the horse. The study utilized 15 donkeys, divided into 3 equal groups $(n=5)$. The radio carpal joint of the right forelimb of donkeys were injected with $25 \mathrm{mg}$ monoiodoacetate (group A), 50mg allogenous cartilage particles (group B), or normal saline (group C) over a period of 70 days. Lameness score, carpal circumference, joint flexion angel, Synovial fluid analysis (total protein and WBC count), were measured weekly over 70 days. There were marked significant change in the clinical signs and synovial fluid analysis between group $A$ and $B$ compared to group C. ACP and MIA in the donkey are suitable models to be investigated as a viable and less expensive alternative for an equine OA model. Injection of ACP may be a good model to study the disease process of osteoarthritis as well as evaluation of diseases modifying osteoarthritis drugs. However, injection on MIA is useful to study the pain effect and acute stage of arthritis as well as evaluation of Non-steroidal anti-inflammatory drugs.
\end{abstract}

Keywords: donkey; lameness; osteoarthritis; cartilage; synovial membrane Abbreviations

ACP: allogenous cartilage particles

MIA: monoiodoacetate

OA: osteoarthritis 


\section{INTRODUCTION}

In the equine industry, lameness due to joint injury and disease is the most prevalent cause of diminished athletic function and wastage in racing horses. Together, joint injury and joint disease represent a large majority of the equine veterinarian caseload. Several epidemiologic studies have found that lameness due to joint disease is the most significant factor responsible for inability to race and loss of performance (Jeffcott et al., 1982 and Wilsher et al., 2006) Therefore, it is important to understand the disease process and treatment options available to the equine practitioner.

Equine OA may be considered as a group of disorders characterized by a common end stage: progressive deterioration of the articular cartilage accompanied by changes in the bone and soft tissues of the joint. The deterioration of the articular cartilage is characterized by local splitting and fragmentation (fibrillation) of articular cartilage. Synovitis and joint effusion are often associated with the disease, and, clinically, the disease is characterized by pain and dysfunction of the affected joint (McIlwraith, 2005).

Animal models are extraordinarily powerful research tools for studying the pathogenesis, diagnosis and potential therapeutic intervention of many different diseases. They provide a key step not only in the knowledge development pathway but also contribute significantly to the "translatability" of drug discovery projects toward clinical realization. The different types of arthritis models have been previously reviewed (Pritzker, 1994; May, 1996 and Little and Zaki, 2012). 
Common features of most experimentally induced osteoarthritis models include the ability to define precisely the type of injury, the severity of injury as well as the time of onset and progression and to relate these events to markers of disease activity (Pritzker, 1994).

Arthritis-like changes have been induced in the horse by Filipin (McIlwraith, and Van Sickle, 1981), Amphotricin (Peloso et al., 1993) (Mokbel et al., 2011), turpentine oil (Singh et al., 1997), polyvinyl alcohol foam (Cornelissen et al., 1998), carrageenan (Owens et al., 1995), complete freund's adjuvant (Toutain and Cester, 2004). lipopolysaccharide (de Grauw et al., 2009), botulinum toxin (DePuy et al., 2007), forced exercise (Murray et al., 2000), osteochondral fragment-exercise model (Frisbie et al., 2009 and McIlwraith et al., 2012).

The MIA arthritis model has been used in rats, chickens, guinea pigs, rabbits and horses, for assessment of the pathophysiologic process as well as evaluation of the efficacy of therapeutic substances in a controlled environment (Gustafson et al., 1992).

Using cartilage particles to induce osteoarthritis was previously described in dog (Chrisman et al., 1965) and rabbit (Evans et al., 1984). A combination of intra-articular injection of cartilage particles, arthroscopic partial thickness cartilage defect and exercise were used to create a model of degenerative joint disease in the horse (Hurtig, 1988). The fate and effects of surgically implanted osteochondral fragments on the middle carpal joint of horses subjected to exercise were investigated (Huber et al., 1992). 
The donkey is properly the closet animal to the horse, making this species an alternative animal model for studying equine diseases. Few papers reported using of donkey as a model of equine OA (Singh et al., 1997 and Mokbel et al., 2011).

In the present study, injections of ACP or MIA were used to create a model of degenerative joint disease in the donkey. The clinical examination and synovial fluid analysis were used to assess the effect of these treatments on healthy cartilage compared to the vehicle control.

\section{MATERIAL AND METHODS}

\section{Donkeys:}

The present study was performed on 15 healthy Egyptian local breed male donkeys weighting from 150 to $200 \mathrm{~kg}$. Animals were housed in indoor stalls and fed on a maintenance ration of mixed grain with hay and unlimited water. All donkeys were dewormed with ivermectine 200 $\mathrm{mcg} / \mathrm{kg}$. body weight. ${ }^{\text {I }}$

Prior to inclusion in the study, lameness examination, body condition, radiographs of carpal joints, range of motion of carpal joints (angle of flexion) and evidence of joint effusion were assessed to ensure that all previous variables were within normal limits (baseline measurement).

Donkeys were allowed to acclimatize for 2 weeks prior to the study. During the acclimatization period, the donkeys trained daily to familiarize them to the experimental conditions (investigators, environment, handling, vein puncture and various outcome measures). 


\section{Cartilage solution preparation:}

Another breed donkey weight $(150 \mathrm{~kg})$ was euthanized, and the articular cartilage was removed from the shoulder, carpal, fetlock, pastern, hock and stifle joints in a biosafety cabinet under aseptic conditions. The pooled cartilage was powdered under liquid nitrogen in a mortar, producing particles as small as $20 \mathrm{~mm}$ in diameter (able to pass easy through a 14-gauge needle). These particles were resuspended at a concentration of $50 \mathrm{mg} / \mathrm{ml}$ in a physiological saline solution ${ }^{\text {II }}$ containing amikacin sulfate ${ }^{\mathrm{III}}(50 \mathrm{mg} / \mathrm{ml})$.

\section{Monoiodoacetate solution preparation:}

MIA were dissolved at a concentration of $25 \mathrm{mg} / \mathrm{ml}$ in a physiological saline solution containing amikacin sulfate $(25 \mathrm{mg} / \mathrm{ml})$.

\section{Study design:}

The 15 donkeys were divided into 3 groups ( 5 of each). Animals were sedated with Xylazine $\mathrm{Hcl}^{\mathrm{IV}}$ in a dose of $1 \mathrm{mg} / \mathrm{kg}$. The skin was aseptically prepared for arthrocentesis of each right radiocarpal joint to obtain synovial sample for baseline analysis. Group A reciened $25 \mathrm{mg}$ (1ml solution) of $\mathrm{MIA}^{\mathrm{V}}$, Group B received $50 \mathrm{mg}(1 \mathrm{ml})$ of ACP and Group C received the suspended solution (1ml) without ACP or MIA (Vehicle - Control group) intra-articulary into the right radiocarpal joint using a $14 \mathrm{G}$ needle. These injections were repeated at 7,14,21,28,35,42 and 56 days for group B and C however Group A received a single MIA injection. 


\section{Outcome measures:}

\section{Clinical Examination:}

Clinical examinations of right forelimbs were performed weekly from day 0 (baseline) and throughout the study period.

\section{Lameness score:}

Donkeys evaluated for lameness score on a scale 0 to 5 according to the American Association of Equine Practitioners (AAEP) grading system (0: Lameness not perceptible with flexion test, 1:Lameness is difficult to observe and is not consistently apparent with flexion test, 2:Lameness apparent with flexion test, 3: Lameness is consistently observable at a trot, 4: Lameness is obvious at a walk. 5:Lameness produces minimal weight bearing in motion) according to Baxster and Stashak, (2011).

\section{Circumference of the carpal joint:}

Measurements obtained at the proximal aspect of the carpus by using of a measurement tape (in $\mathrm{cm}$ ), and with the aid of the anatomical reference points (accessory, radial, ulnar and intermediate carpal bones). Circumference was obtained weekly; hair over the selected area was clipped on a regularly scheduled basis (Toutain and Cester, 2004).

\section{Maximum carpal flexion angel:}

Maximum carpal flexion was measured weekly by slowly flexing the carpus until the donkey resisted. The angle was then measured in degrees with goniometer (Toutain and Cester, 2004). 
Synovial fluid analysis:

Synovial fluid sample $(1 \mathrm{ml})$ was aseptically aspirated from each joint before each injection. The conventional analysis of synovial fluid included assessment of total protein concentration, white blood cell (WBC) count, and according to Frisbie et al., (2009). Total protein concentrations and WBC were determined via Double Beam UV Visible Spectrophotometer and use of an automated cell counter, respectively.

\section{Statistical analysis:}

Variables including lameness, carpal flexion angel, carpal circumference, TP and TWBC count were analyzed using analysis of variance (ANOVA) model with SPSS ${ }^{\mathrm{VII}}$. Any test with a $\mathrm{P}$ value $<0.05$ was declared statistically significant. When individual comparisons were made, Bonferroni post hoc test was used and $\mathrm{P}<0.05$ was considered significant. The Values are reported as mean \pm Standard deviation.

\section{RESULTS}

\section{Clinical Examination:}

\section{Lameness score:}

Increasing in the lameness score began at day 7 for group A, and at day 14 for group B and peak at day 14 for group A and at day 21 for group B. At day 56, the lameness score was at lowest value for group A and B. Group C had no lameness all over the study period (Fig. 1). 
There was a significant changes between group $\mathrm{A}$ and groups C $(\mathrm{P}<0.001)$ at each study day. However, group B was significantly different from group $\mathrm{C}$ at day 21, 28, 35 and 42. Group $\mathrm{A}$ was significantly difference from group $\mathrm{B}$ at days 7,14 and $42(\mathrm{P}<0.05)$ (Fig. 1).

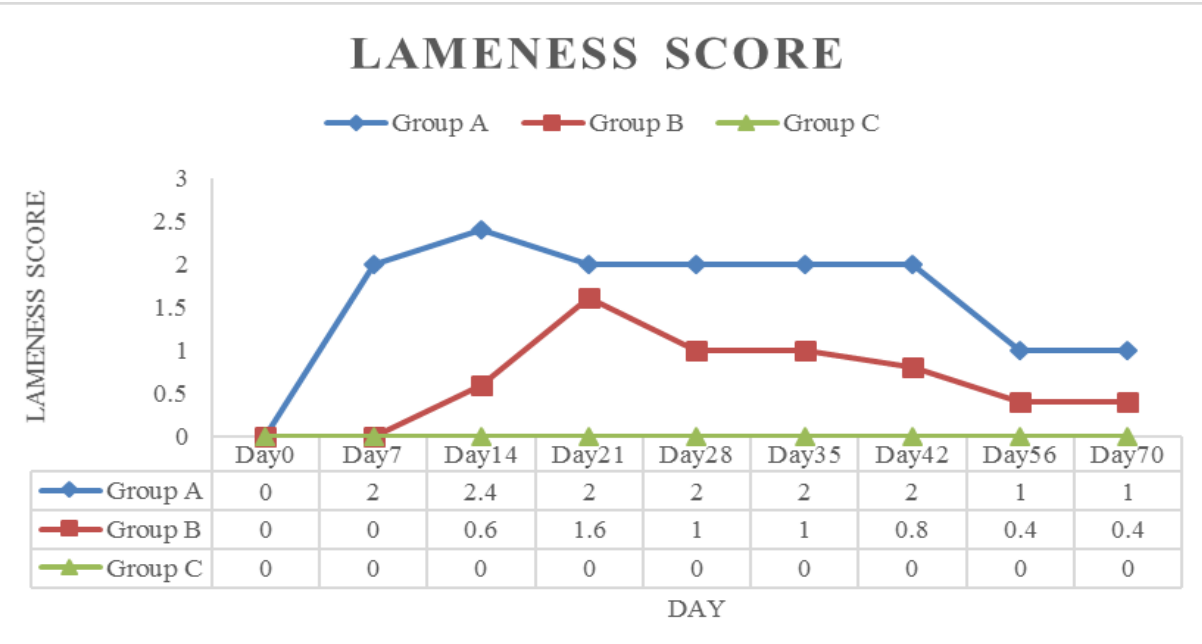

Fig. (1): Mean lameness score for groups $A, B$, and $C$ all over the study period.

\section{Carpal Circumference:}

Circumference in group A was strongly increased at day 7 then began to decline till the end of the study. However, Group B was smoothly increased reaching the peak at day 35 then began to decrease until the study end. Group $C$ was weakly increased but not significantly changed. Group A was significantly different from group $\mathrm{C}$ at each study day $(\mathrm{P}<0.05)$ and was significantly different from group $\mathrm{B}$ at day 7,14 , 21, 28, 56 and 70. However, Group B and C were not significantly different from each other (P>0.05) (Fig. 2). 


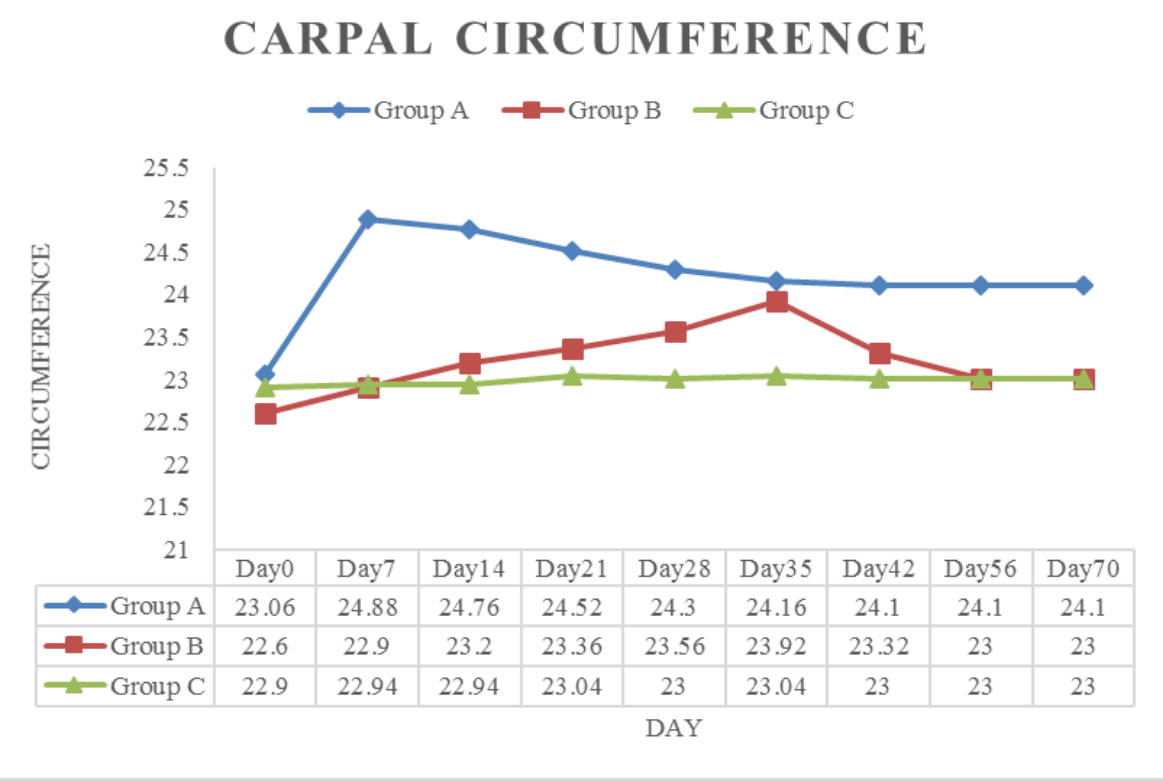

Fig. (2): Mean carpal circumference for groups A, B, and C all over the study period

\section{Maximum carpal flexion angel:}

The flexion angel suddenly decreased at day 7 in-group $A$ then began to decrease smoothly until the end of the study. Group B decreased smoothly until reach the peak at day 35 then began to increase to the end of the study. Group $\mathrm{C}$ had a constant flexion angle throughout the study period (Fig. 3).

Group A was significantly different from group B and C on each study day $(\mathrm{P}<0.05)$. However, group $\mathrm{B}$ was significantly different from group $\mathrm{C}$ from day 21 until day 42 (Fig. 3). 


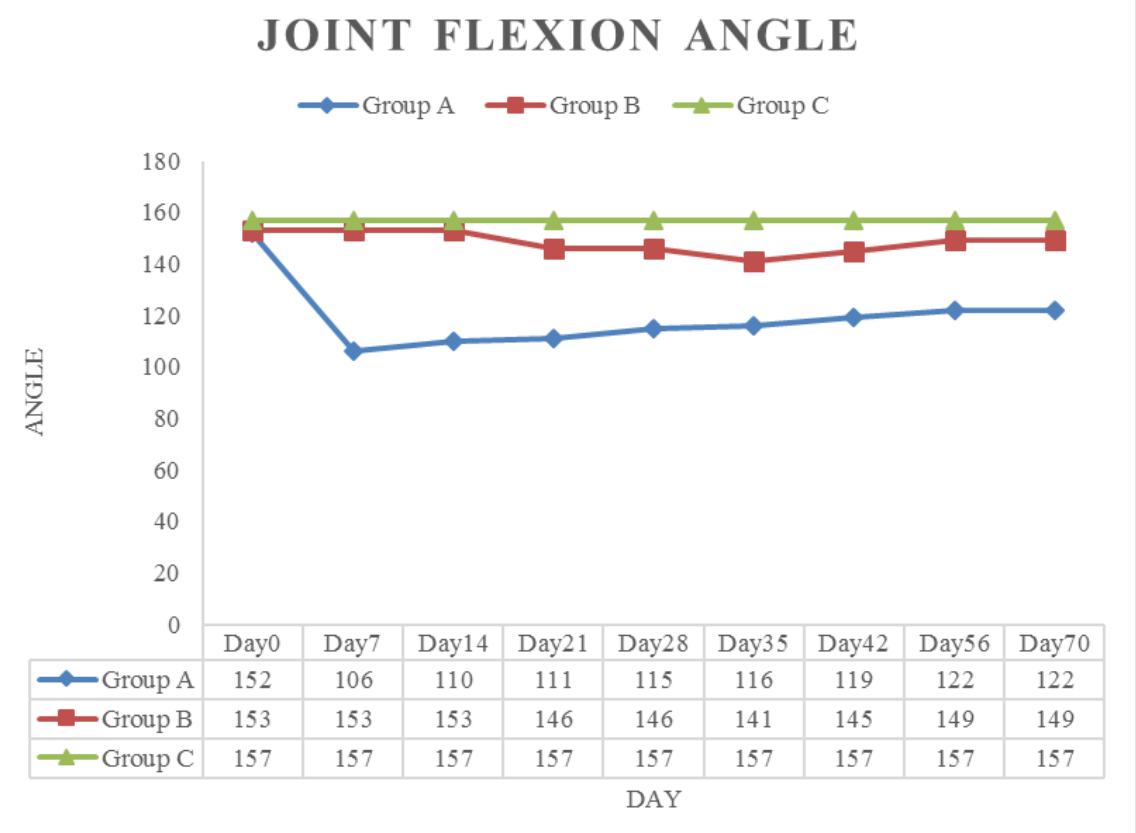

Fig. (3): Mean carpal flexion angle for groups A, B, and C all over the study period

\section{Synovial fluid analysis:}

Synovial WBC count was increased at day 7 in all groups. Group A reached its peak at day 7, group B at day 35 and group C at day 42 (Fig. 4).

Group A was significantly different from group B and C on each study day $(\mathrm{P}<0.05)$. However, group B was significantly different from group C on study day 14, 21, 28, and 35 (Fig. 4). 


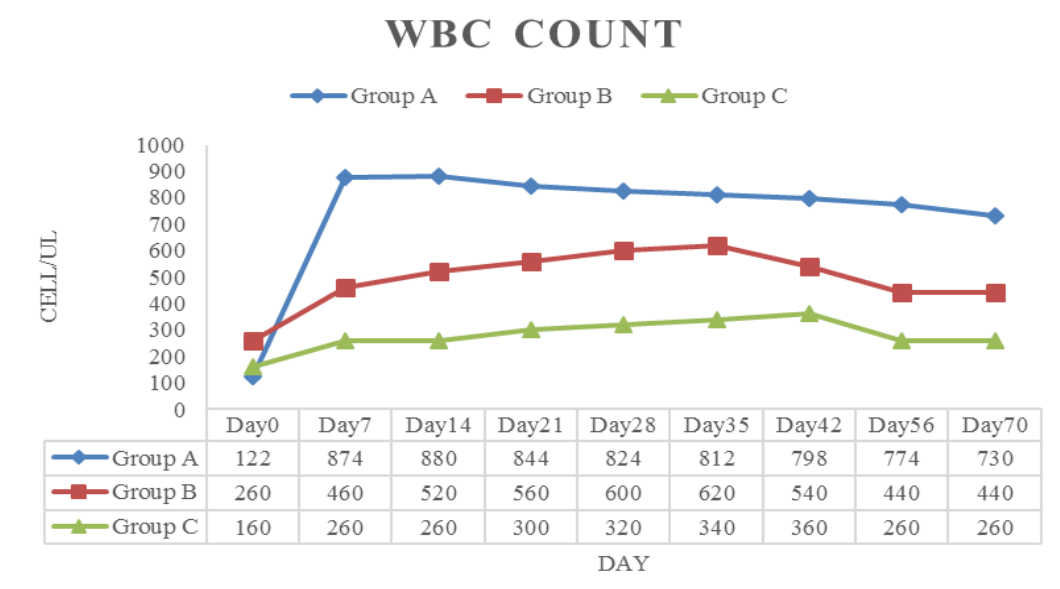

Fig. (4): Mean WBC count for groups $A, B$, and $C$ all over the study period.

Total protein also increased in Group A, Group B and Group C after the first injection throughout the study. Group A was significantly different from group $\mathrm{B}$ and $\mathrm{C}(\mathrm{P}<0.05)$ but Group $\mathrm{B}$ and $\mathrm{C}$ were not significantly different from each other (Fig. 5).

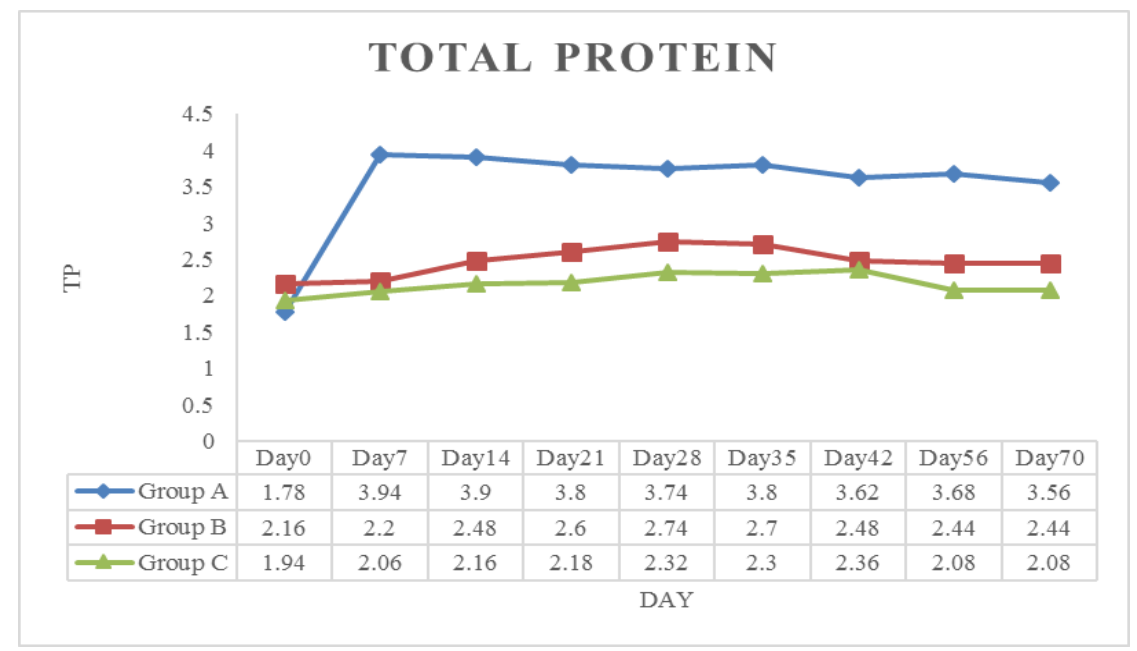

Fig. (5): Mean total protein score for groups A, B, and C all over the study period 


\section{DISCUSSION}

Many models of OA in animals exist, however none of the existing models perfectly resemble the natural disease (Little and Zaki, 2012).

In the horse, complete surgical transection of the cranial cruciate ligament in horses has not resulted in progressive OA like other species (Kawcak, 2011). Carrageenan (Owens et al., 1995) and Polyvinyl alcohol foam (Cornelissen et al., 1998) induces transient lameness, but only for a short period. Application of Escherichia coli lipopolysaccharide (LPS) (de Grauw et al., 2009), Amphotricin (Peloso et al., 1993) or the polyene antibiotic filipin (McIlwraith and Van Sickle, 1981), Freund's complete adjuvant (Toutain and Cester, 2004) are well-described models, but use of either can result in severe, nonweight-bearing lameness, induce irreversible osteophytosis and articular lesions. In addition, all these agents can result in substantial increase in the circumference of the joint, compared with that of the control joint, owing to severe inflammatory response in the periarticular tissues.

In the osteochondral fragment models, the animals are subjected to very invasive surgery with postoperative antibiotics and non-steroidal anti-inflammatories that may affect the function of the body system. In addition, induction of the chondral defects lack the natural sequence of the disease process.

To study osteoarthritis in horses we should use an animal model phylogenetically, biomechanically and biochemically close as is possible in order to most accurately reflect pathologic process in the target species (May, 1996). Thus for horse a donkey model is likely to be superior to a dog, rabbit or mouse model. 
In the present study, intraarticular injection of allogenic cartilage particles or monoiodoacetate effectively resulted in clinical, histologic, and biochemical changes indicative of osteoarthritis. Lesions are vary from mild osteoarthritis with superficial cartilage fibrillation to moderate osteoarthritis with cartilage erosion. During this study, no adverse events were recorded with any of the treatment doses and a mild degree of lameness was induced.

MIA act by inhibiting the glyceraldehyde-3-phosphate dehydrogenase activity in the chondrocytes (an inhibitor of glycolysis) promotes loss of articular cartilage similar to that noted in human OA (Guzman et al., 2003). In the absence of an effective treatment, the model will induce pathological detectable features of OA (Gustafson et al., 1992).

The mechanisms of action $\mathrm{o} A \mathrm{ACP}$ to create cartilage erosion is controversial, but probably occurs by two mechanisms. First, cartilage particles may initially act as abrasives to liberate more 'wear particles' which are engulfed by the synovial membrane causing metaplastic changes in the membrane, abnormal synovial fluid constituents and synovitis. Secondly, cartilage particles may also stimulate synovial cells via immune system to produce cellular mediators and/or proteinases which result in depletion of cartilage matrix, either directly or by acting on the chondrocytes (Hurtig, 1988).

MIA dose used upon previous work in horse where $0.16 \mathrm{mg} / \mathrm{kg}$ was used. (Gustafson et al., 1992) ACP dose was made upon previous work with rabbit where $1 \mathrm{mg} / \mathrm{kg}$ was used. (Evans et al., 1984). Repeated injection of $\mathrm{ACP}$ is needed to accelerate a natural degenerative process that normally takes years to develop. 
Lameness is often a feature of natural or experimentally induced OA. In some cases, lameness may be severe that limits usefulness of a model (McIlwraith and Van Sickle, 1981) .despite the fact that articular cartilage degeneration was induced in our study, lameness was a major feature of MIA group in contrast to the ACP groups.

Carpal circumference and joint flexion angel changes were changed strongly in MIA group after the first injection that mimic the acute traumatic joint disease with local pain on pulpation this is an indicator for synovitis and/or joint capsule fibrosis. in contrast to the ACP group giving the MIA the priority to be a good model for acute synovitis.

There was some variability in the degree of articular cartilage changes within the same group; this may be due to imperfect correlation between body weight and carpal diameter.

\section{Conclusion:}

Injection of ACP may be a good model to study the disease process of osteoarthritis as well as evaluation of diseases modifying osteoarthritis drugs. However, injection on MIA is useful to study the pain effect and acute stage of arthritis as well as evaluation of Non-steroidal antiinflammatory drugs.

\section{Authors' declaration of interests:}

There are no conflicts of interest.

\section{Sources of funding:}

We thank Biopharm Australia for generous financial support. The work performed was not influenced at any stage by the support provided. 
Manufacturers' addresses:

Equiven (oral paste) The Egyptian Co. For chemicals \& Pharmaceuticals (ADWIA).

Sodium chloride 0.9\% W/V I.V. infusion: El nasr Pharmaceutical chemicals Co. Egypt.

Amikin. Bristol Meyer Squiip Egypt.

Xylaject: The Egyptian Co. For chemicals \& Pharmaceuticals (ADWIA).

Sodium monoiodoacetate (MIA) (25gm): ICN, Biomedicals GmBH Thuriger star be 15.Germany

Nembutal Sodium: 20-mL vial contains 1000mg pentobarbital sodium. Lundbeck Inc. Deerfield, IL 60015. U.S.A.SPSS Statistics Version 17: WinWrap Company release 2008

SPSS Statistics Version 17: WinWrap Company release 2008

\section{REFERENCES}

- Baxster GM and Stashak TS (2011). Examination for Lameness. In G. Baxter, Adams and Stashak's lameness in horses. - 6th ed. (pp. 128-168). Blackwell Publishing, Ltd.

- Chrisman OD, Fessel JM, Stouthwick WO (1965). experimental production of synovitis and marginal articular exostosis in the knee joint of dogs. Yale Journal of biology and medicine, 37. 
- Cornelissen BP, Rijkenhuizen AB, van den Hoogen BM, Rutten VP, Barneveld A. (1998). Experimental model of synovitis/capsulitis in the equine metacarpophalangeal joint. Am J Vet Res., 59(8), 978-985.

- De Grauw JC, van de Lest CH, Brama PA, Rambags BP, van Weeren PR. (2009). In vivo effects of meloxicam on inflammatory mediators, MMP activity and cartilage biomarkers in equine joints with acute synovitis. Equine Vet J., 41(7), 693-699.

- DePuy T, Howard R, Keegan K, Wilson D, Kramer J, Cook JL, Childers MK. (2007). Effects of intra-articular botulinum toxin type A in an equine model of acute synovitis: a pilot study. Am J Phys Med Rehabil. , 86(10), 777-783.

- Evans, C.H., Mazzocchi, R.A., Nelson, D.D., Rubash, H.E. (1984). Experimental arthritis induced by intraarticular injection of allogenic cartilagenous particles into rabbit knees. Arthritis and Rheumatism, 27(2).

- Frisbie DD, Kawcak CE, McIlwraith CW, Werpy NM (2009). Evaluation of polysulfated glycosaminoglycan or sodium hyaluronan administered intra-articularly for treatment of horses with experimentally induced osteoarthritis. AJVR, 70(2).

- Gustafson SB, Trotter GW, Norrdin RW, Wrigley RH, Lamar C. (1992). Evaluation of intra-articularly administered sodium monoiodoacetate-induced chemical injury to articular cartilage of horses. Am J Vet Res, 53(7), 1193-202. 
- Guzman RE, Evans MG, Bove S, Morenko B, Kilgore K (2003). Mono-iodoacetate-induced histologic changes in subchondral bone and articular cartilage of rat femorotibial joints: an animal model of osteoarthritis. . Toxicol Pathol, 31(6), 619-24.

- Huber MJ, Schmotzer WB, Riebold TW, Watrous BJ, Synder SP, Scott EA, Von Matthiessen PC (1992). Fate and effect of autogenous osteochondral fragments implanted in the middle carpal joint of horses. Am J Vet Res, 53(9).

- Hurtig M (1988). Use of autogenous cartilage particles to create a model of naturally occurring degenerative joint disease in the horse. Equine orthopedic injury and repair. Equine veterinary journal supplement 6, 19-22.

- Jeffcott LB, Rossdale PD., Freestone J, Frank CJ, Towers Clark PF (1982). An assessment of wastage in thoroughbred racing from conception to 4 years of age. Equine Vet J., 14(3), 185-198.

- Kawcak CE (2011). Models of Equine Joint Disease. In Diagnosis and Management of Lameness in the Horse (pp. 673-677). Colorado: Saunders.

- Little, C.B and Zaki, S (2012). What constitutes an "animal model of osteoarthritis" e the need for consensus? Osteoarthritis and Cartilage, 20, 261-267. 
- May SA (1996). Animal models and other experimental system in the investigation of equine arthritis. In M. CW, joint diseases in the horse (pp. 421-440). Philadelphia: Saunders.

- McIlwraith $\boldsymbol{C W}$ (2005). From Arthroscopy to Gene Therapy-30 Years of Looking in Joints. AAEP PROCEEDINGS. 51. Seattle, WA, USA: American Association of Equine Practitioners.

- McIlwraith CW and Van Sickle DC (1981). Experimentally induced arthritis of the equine carpus: histologic and histochemical changes in the articular cartilage. Am J Vet Res., 42(2), 209-217.

- McIlwraith CW, Frisbie DD, Kawcak CE (2012). Evaluation of intramuscularly administered sodium pentosan polysulfate for treatment of experimentally induced osteoarthritis in horses. AJVR, 73(5), 628-633.

- Mokbel AN, El Tookhy OS, Shamaa AA, Rashed LA, Sabry D, El Sayed AM. (2011). Homing and reparative effect of intra-articular injection of autologus mesenchymal stem cells in osteoarthritic animal model. BMC Musculoskelet Disord., 12, 259.

- Murray RC, Janicke HC, Henson FM, Goodship A (2000). Equine carpal articular cartilage fibronectin distribution associated with training, joint location and cartilage deterioration. Equine Vet J., 32(1), 47-51. 
- Owens JG, Kamerling SG, Barker SA. (1995). Pharmacokinetics of ketoprofen in healthy horses and horses with acute synovitis. J Vet Pharmacol Ther., 18(3), 187-195.

- Peloso JG, Stick JA, Caron JP, Peloso PM, Soutas-Little RW (1993). Effects of hylan on amphotericin-induced carpal lameness in equids. Am J Vet Res., 54(9), 1527-1534.

- Pritzker, K (1994). Animal models for osteoarthritis: processes, problems and prospects. Annals of the Rheumatic Diseases , 53, 406420.

- Singh KI, Sobti VK, Roy KS (1997). Gross anHistomorphological effects of therapeutic ultrasound in experimental acute traumatic arthritis in donkeys. Journal of Equine Veterinary Science, 17(3), 150155.

- Toutain PL and Cester CC (2004). Pharmacokinetic-pharmacodynamic relationships and dose response to meloxicam in horses with induced arthritis in the right carpal joint. Am J Vet Res, 65(11), 1533-1541.

- Wilsher S, Allen WR, Wood JL (2006). Factors associated with failure of thoroughbred horses to train and race. Equine Vet J., 38(2), $113-8$. 
دراسة تجريبية مقارنة في الطرق المختلفة لعمل التهاب مفصلى في الفصيلة الخيلية ط.ب. احمد المسيرى1 1 ، أ. . على عبد القادر منصور2 أ.د. مجدى عبد الحميد سليم3 3 1- قسم الرعاية البيطرية ـ مديرية الطب البيطرى بالغربية 2- قسم النشريح والاجنة ـ كلية الطب البيطرى جامعة كفر الثيخ 3- قسم الجراحة والتخدير و الاثعة ـ كلية الطب البيطرى جامعة كفر الثيخ

النمـاذج الحيوانيـة للالتهاب المفصـلى ضـرورية لدراسـة كيفيـة حدوث المـرض و لتقيـيم الطـرق المختلفة للعلاج. هذا والجدير بالذكر انه حتى الان لايوجد نموذج حيوانى مثالى للالتهاب المفصلى. -هذه الدراسـة هي محاولة لايجاد نموذج حيوانى للالتهاب المفصلى يماثل الالتهاب الطبيعى الذى يحدث في الفصيلة الخيلية.

$$
\text { -حيث نم استخدام } 15 \text { حمار مقسمين الى ثلاثة مجموعات (المجموعة = 5) }
$$

وكان منهج البحث تم حقن مفصل الركبة الأيمن الامسمى لحمير المجموعة (أ) بخمسة وعثرين مجم من مستحضر المونوايودو اسيتات والمجموعة (ب) بخمسين مجم من مستحضرجزيئات غضروفية بينما المجموعة (ج) تم حقنها بمحلول ملحى على مدى 70 يوم. -تمت متابعة تاثز المعاملات من خلال تقييم معدل العرج وقياس كلا من زاوية ثنى الركبة و محيط مفصل الركبة و تحليل السائل المفصلى أسبوعيا على مدار 70 يوم. وبعد تحليل النتائج احصائيا وجد تغير ملحوظ في الاعراض الظاهرية للاتهاب المفصلى وكذلك تحليل السـائل المفصـلى بـين المجمـوعتين أ و ب مقارنـة بالمجموعـة ج. وبـللك أوضـحت النتائج ان

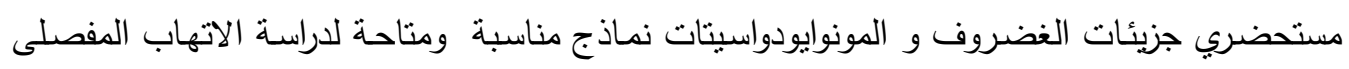
كما تعتبر بدائل غير مكلفة كنموذج للالتهاب المفصلى في الخيول. كما نبين أيضا ان حقن جزبئات الغضروف يمكن ان يكون نموذج جيد لدراسة المراحل المرضية للالتهاب المفصلى بالإضـافة الى تقييم ادوية تاكل الغضـاريف بينما المونوايودواسيتات يعتبر مفيد في دراسـة تاثير الألم خصوصسا في حالات الالتهاب المفصلى الحاد بالإضافة الى تقييم الادوية المسكنة و مضادات الالتهاب. 